Journal of Scientific Perspectives

Volume 4, Issue 4, Year 2020, pp. 281-288

E - ISSN: 2587-3008

URL: https://journals.gen.tr/jsp

DOİ: https://doi.org/10.26900/jsp.4.025

Research Article

\title{
AN ENDEMIC PLANT GROWING IN KAZDAĞI IMPORTANCE AND USAGE AREAS OF Euphorbia anacampseros Boiss. var. anacampseros TAXON
}

\author{
Gizem TUTGUN* \& Ahmet GÖNÜZ** \\ *PhD Student Çanakkale Onsekiz Mart University, \\ Graduate School of Natural and Applied Sciences, TURKEY, \\ e-mail: gizemtutgun@gmail.com \\ ORCID: https://orcid.org/0000-0001-7726-9655 \\ **Prof. Dr., Çanakkale Onsekiz Mart University, \\ Faculty of Science and Arts, Department of Biology, \\ Subdivision of General Biology, TURKEY, e-mail: ahmetgonuz3@gmail.com \\ ORCID: https://orcid.org/0000-0002-4571-0378
}

\section{ABSTRACT}

Morphological and anatomical characteristics of Euphorbia anacampseros Boiss. var. anacampseros taxa which is an endemic member of Euphorbiaceae family were investigated. Morphological characteristics and dimentions of these specimens were collected from Kazdagl National Park. Anatomical features (like cross-sections of the root and stem, cross and superficial sections of the leaf) of taxon were investigated.

Keywords: Euphorbia anacampseros, Boiss. var., anacampseros, endemic, morphology, anatomy, laticifer, usage areas, cancer 


\section{INTRODUCTION}

There is biological diversity on earth in the food chain. Many living species are connected each other in terms of the continuity of life and need to exist in the same process. Nowadays, Euphorbiaceae family which is increasingly importance and popularity in researches for cancer treatment, consists of succulent milky plants with mostly herbaceous forms and single or perennial species.

It is known that the Euphorbiaceae family is represented by approximately 8910 species in the world (Bercu and Popoviciu, 2015). The cosmopolitan of this family includes 300 genera and 102 species (Seçmen et al., 2004), but endemic ones are kept its importance, too. It has been recorded in our country are in the LC category (widely distributed and abundant species are placed in this category (Eken et al., 2006), according to the International Union for Conservation of Nature (IUCN) (Özgişi et al., 2017; Çalışkan, 2010; Yeşilyurt and Akaydın, 2017).

\subsection{Study Areas}

It constitues the border between the Euxine Region of the European-Sibirian Region and the Eastern Mediterranean Region (Ayaşlıgil, 2006), when Kazdağ1 is examined phytogeographically. The fact that Kazdağ 1 is where the climatic characteristics and the three floristic regions (Özhatay et al., 2005; Gemici and Özel, 2001) meet increases the biodiversity in the region and its importance accordingly.

Fig 1: Floristic regions of Turkey (Avc1, 1993)

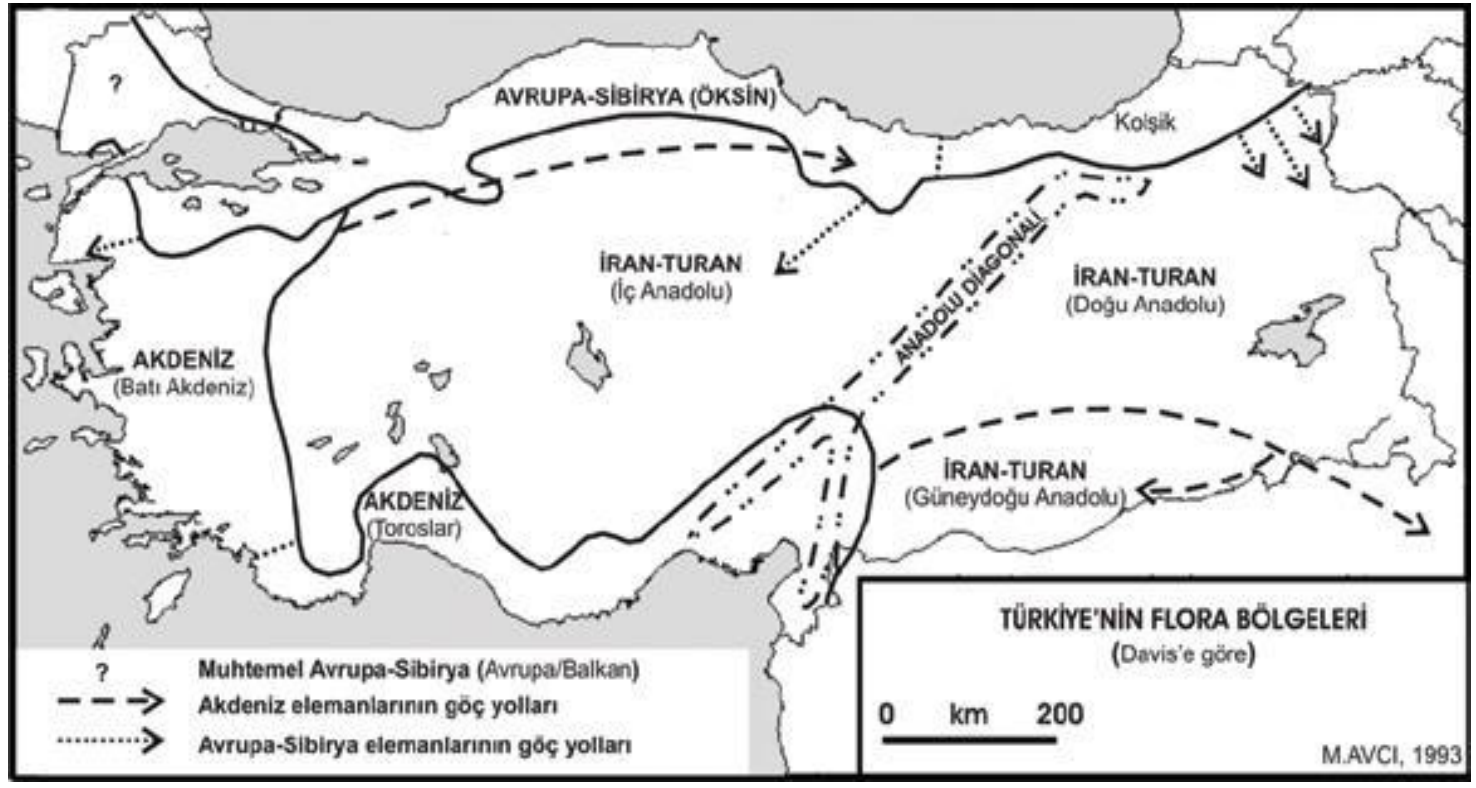

\subsection{Usage Areas}

It is known that some species of the Euphorbia anacampseros taxon are used for hunting by poisoning fish in rivers and lakes, and also causes poisoning by being given directly against some species such as malaria and jaundice and the risks posed by warts in terms of human health. In addition, it has been reported that the unconscious use of family members in medicine, raw materials in industry, and among the public causes an increae in cancer due to the risk factor of diterpenester (a chemical compounds) (Hecker, 1986). When the recent sources are examined (Luz et al., 2015; Mali and Jadhav, 2015; Erbay et al., 2018; Schippmann, 2018; Aylward et al., 2016; Avc1, 1993) in citotoxicity studies, especially in cancer, would healing, dental and acne treatment, industry and pharmaceutical industry, rubber extraction from latex 
material, dye raw material, cultivation as ornamental plant and wax making, again, it seems that the latex material has a positive effect on the application of the chemical 'Ingenol angelate' used to suppress the growth of melanoma cells.

\section{MATERIAL AND METHODS}

In our study, E. anacampseros Boiss. var. anacampseros taxon has been chosen as the research subject. As a method, in the areas where the study taxon naturally grows in the Kazdağ National Park (from a weight of $600-700 \mathrm{~m}$ on 30.05 .2019 , its locality was determined on 10.07.2019), considering that the taxon is endemic, a sufficient number of herbarium name, morphological measurements and anatomical cross-sectional studies, and alcohol materials of the specimens were prepared.

Plant specimens don't have locality and herbarium number. were brought to the laboratory under suitable conditions and morphological measurements such as plant height and width, leaf height and width were taken and comparisons were made with the size details defined in the work named 'Flora of Turkey and East Aegean Islands' (Davis, 1982) (Table 1).

Table 1. Comparison of the morphological measurements of Euphorbia anacampseros Boiss. var. anacampseros

\begin{tabular}{|c|c|c|}
\hline Davis (1982) & Genç (1989) & Tutgun (2020) \\
\hline $\begin{array}{l}\text { Root; decumbent and rarely } \\
\text { exceed } 20 \mathrm{~mm} \text {. }\end{array}$ & Root; branched out. & Root; branched out and $1-5,5 \mathrm{~cm}$. \\
\hline $\begin{array}{l}\text { It has been defined as perennial } \\
\text { plants that are glabrous, drooping } \\
\text { and rising from below at family } \\
\text { level. }\end{array}$ & $\begin{array}{l}\text { The umbella structure at the top } \\
\text { of the body is rarely } 3-5 \text { beams, } \\
\text { rays } 2-2.5 \mathrm{~cm} \text {. }\end{array}$ & $\begin{array}{l}\text { Stem length } 16.5-25 \mathrm{~cm} . \text {, width } \\
0.4 \mathrm{~cm} .\end{array}$ \\
\hline $\begin{array}{l}\text { Cauline leaves } 20 \mathrm{~mm} . \text {, raylet } \\
\text { leaves; } 17 \mathrm{~mm} \text {. and its } \\
\text { dimentions }(5-) 10-35(-40) \times(3-) \\
10-35(-40) \mathrm{mm} .\end{array}$ & $\begin{array}{l}\text { Cauline leaves; leathery, fleshy, } \\
\text { sesile, frequently alternating }(0,9- \\
1,6 \mathrm{~cm} .), \text { ovate-rhombic, obovate, } \\
\text { mukronate at the top, acute- } \\
\text { acuminate, very fine toothed } \\
\text { edges, side veins indistinct, leaf } \\
\text { color mostly reddish pink, } \\
\text { branching dichotomous up to } 1 \text { or } \\
2 \text { times. }\end{array}$ & $\begin{array}{l}\text { Leaves; length } 2.2,2.4 \text { and } \\
\text { between } 2.5 \mathrm{~cm} ., \text { width } 1.3,1.4 \\
\text { and between } 1.5 \mathrm{~cm} ., \text { shape } \\
\text { suborbiculate, margin entire, apex } \\
\text { large and mucronate, color } \\
\text { generally purplish. }\end{array}$ \\
\hline
\end{tabular}

Speciments were taken into a 70\% ethyl alcohol solution prepared on the same day and fixed for 24 hours. The fixed specimens were protected at $+4{ }^{\circ} \mathrm{C}$ in the refrigerator. The cross and superficial section were taken for stem, body and leaf tissue examinations.

\subsection{Anatomical Features of the Root}

In cross-sectional examinations, there is suberinized and ligninized rhizoderm tissue on the outermost part and cannot be observed since the epiderma cells are crushed. Just below is the is the parenchymal cortex tissue consisting of an average of 10 cell lines. In the cortex tissue, there are secretory cells that carry latex. Under the cortex tissue, there is a conduction tissue showing a collateral structure. Phloem tissue occupies less space in general than xylem tissue cells, and cambium is not very prominent. There is a sclerenchymal pith under the conduction issue and in the inner most region (Fig 2). 
Fig 2. Root cross-section of Euphorbia anacampseros Boiss. var. anacampseros: R:Rhizoderm, Ko: Kortex, Fl: Phloem, Ks: Xylem, La: Laticifer

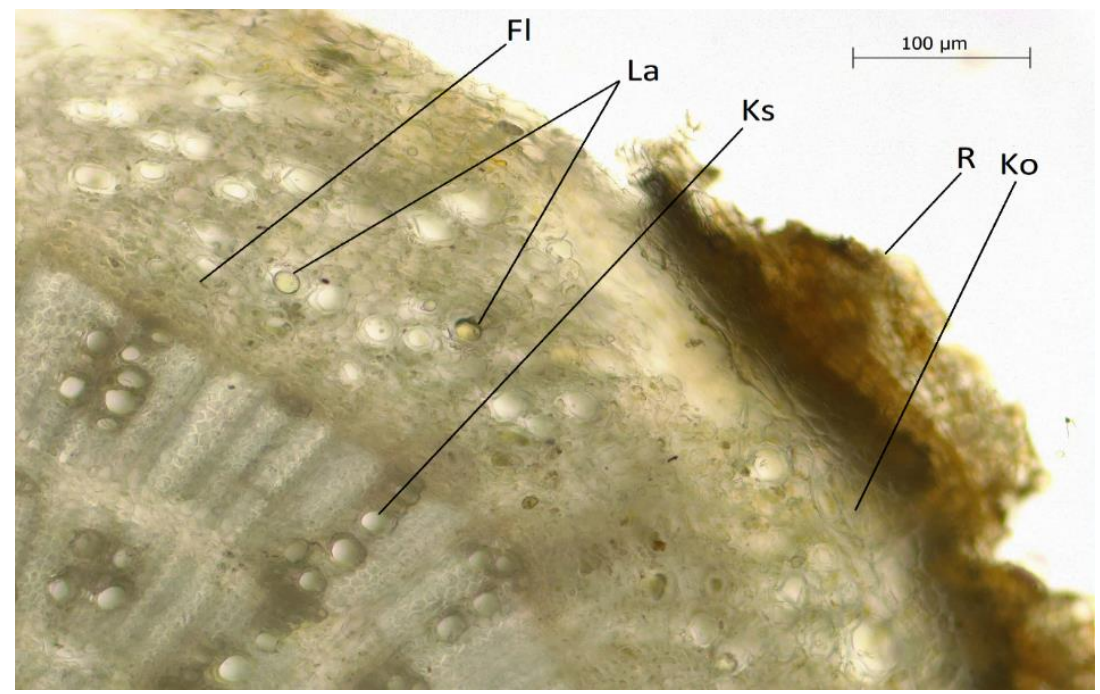

\subsection{Anatomical Features of the Stem}

There are papillose structures in the cuticular tissue from the outside to the inside. Collencymatic tissue is located just below the single-row epidermic cells. The cortex tissue is composed of 12-16 rows of parenchymal cells in places and contains a number of latex-bearing cells that can be evaluated densely. In addition, milk pipers are located in the cortex tissue in places. From the end of the cortex cells, phloem tissue and xylem tissue just below respectively, form the collateral bundles. Cambium is not obvious. There are pith rays between the vascular bundle. Under the vascular tissue and in the innermost region there is the parenchymal pith. There are milk tubes containing latex between the pith tissue and the parenchyma cells. In crosssections taken from well developed roots, it was observed that the pith regions were fragmented (Fig 3, 4).

Fig 3: Stem cross-section of Euphorbia anacampseros Boiss. var. anacampseros: P: Papillose E: Epidermis Ko: Cortex, La: Laticifer, Fl: Phloem, Ks: Xylem Ö: Pith region

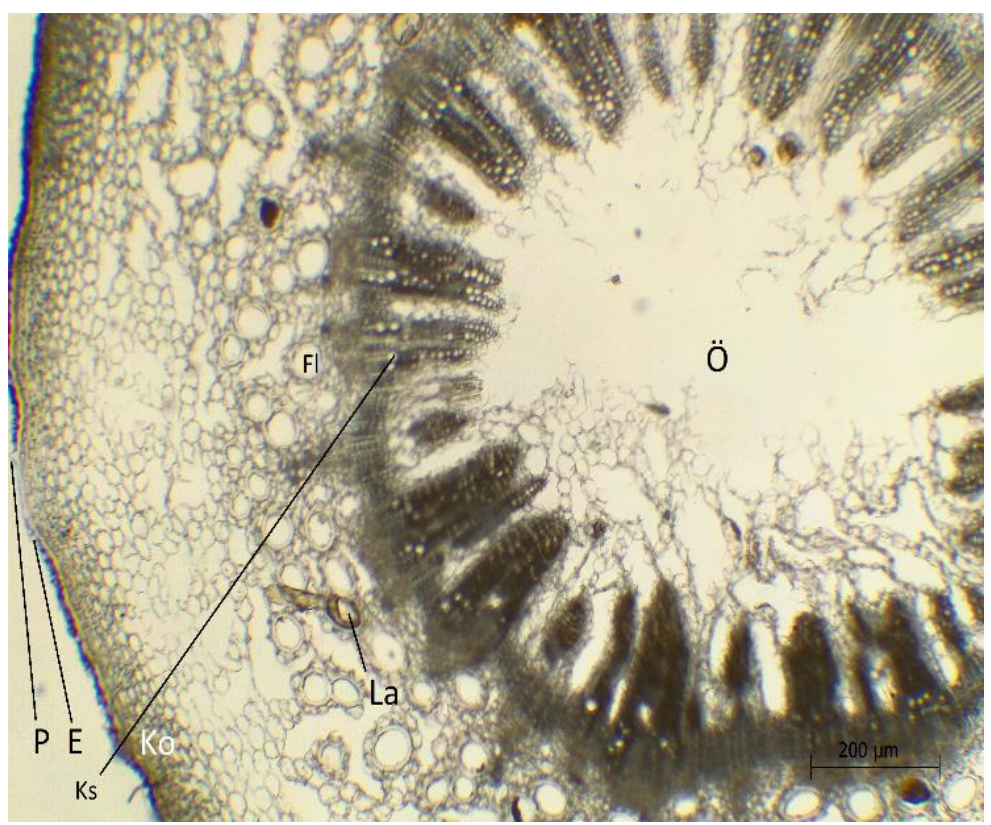


Fig 4: Stem cross-section of Euphorbia anacampseros Boiss. var. anacampseros: P: Papillose, K: Cuticle, E: Epidermis, Kol: Collenchyma, Ko: Cortex, La: Laticifer, İl: Vascular bundle, Ö: Pith region

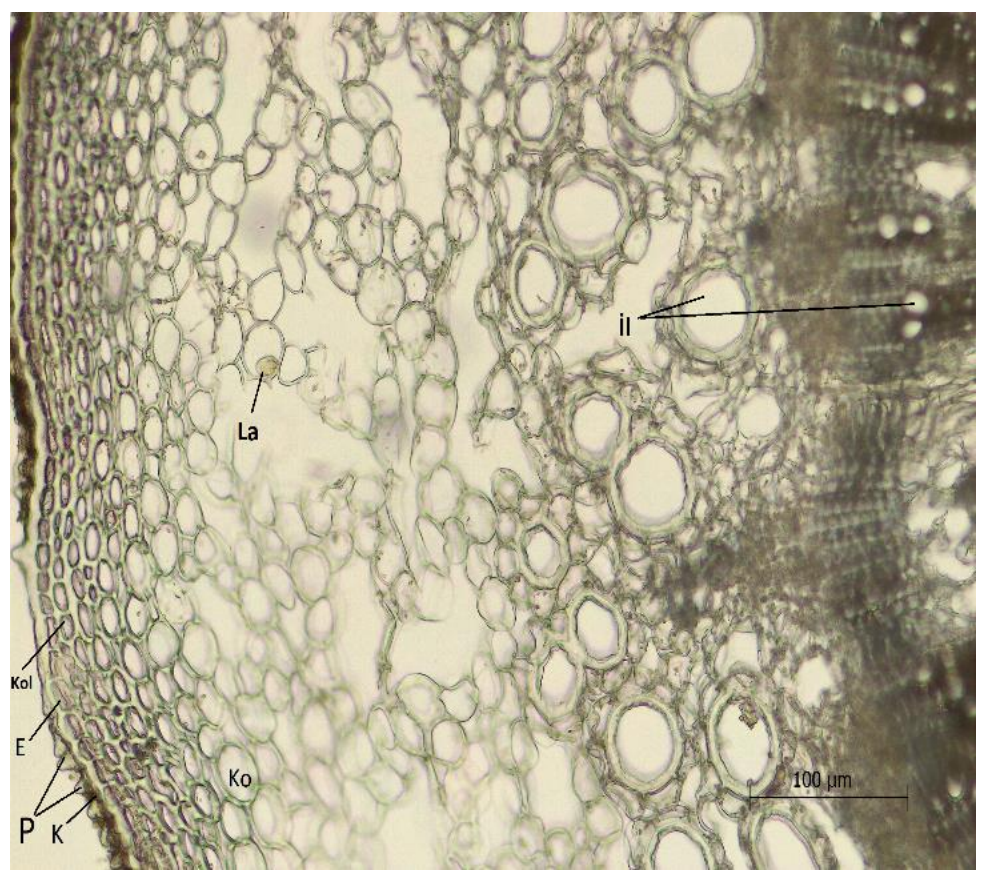

\subsection{Anatomical Features of the Leaf}

The leaf is bifacial. From the outside to the inside, there are papillose structures in both the upper and lower tissue. Epidermis cells are in a single row under a thick cuticle layer. In the upper epidermal structure, there are 2-4 rows of palisade parenchyma cells with dense chloroplasts, sponge parenchyma cells with large intercellular areas just below. Vascular bundles are in collateral type. There are latex-bearing secretory cells throughout the mesophyll tissue. Stomas are of amphistomatic type. Stomata were observed to be anomocytic in the superficial sections taken from the leaves (Fig 5, 6).

Fig 5: Leaf cross-section of Euphorbia anacampseros Boiss. var. anacampseros: P: Papillose, K: Cuticle, E: Epidermis, Pa: Palisade parenchyma, Sü: Sponge parenchyma

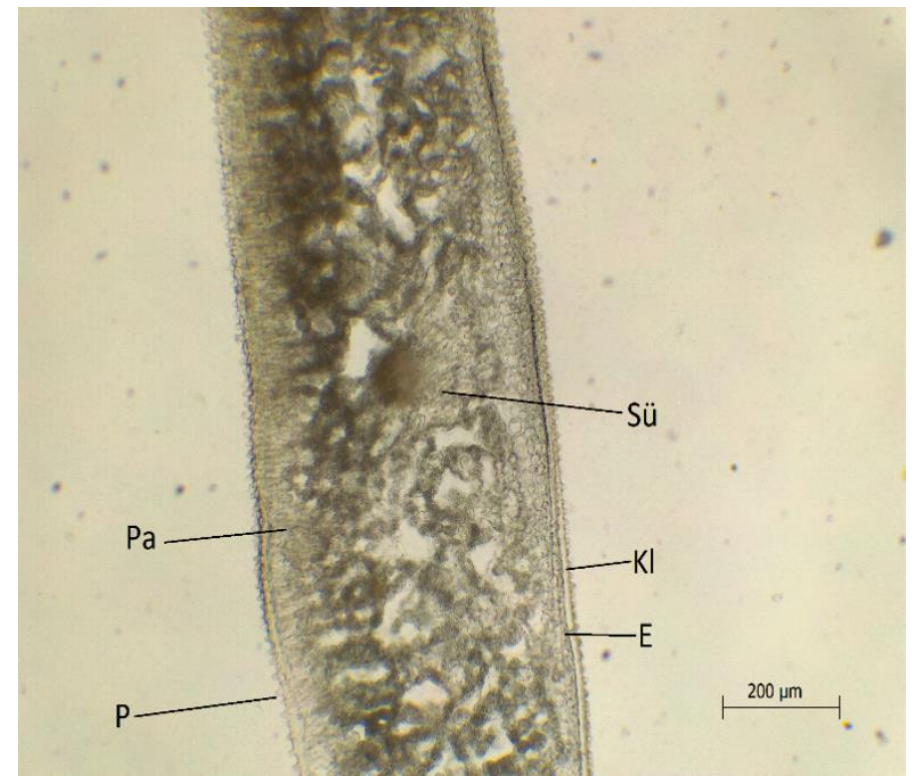


Fig 6: The appearance of stoma cells in leaf superficial section of Euphorbia anacampseros Boiss. var. anacampseros

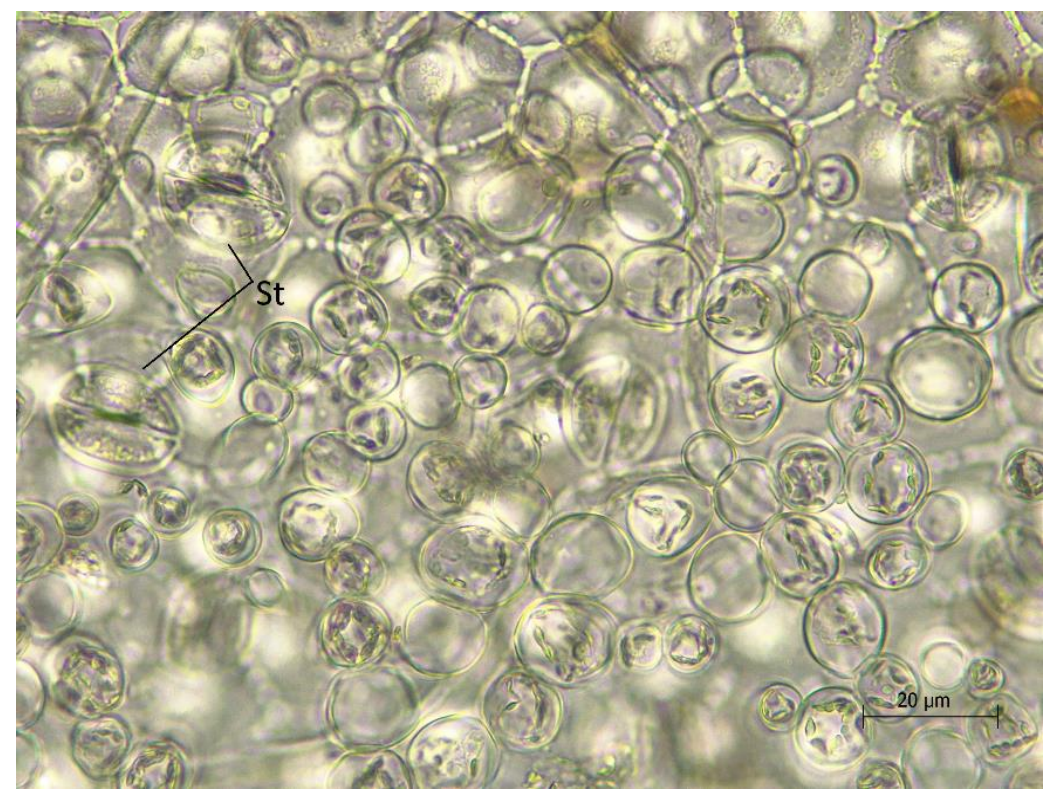

\section{DISCUSSION}

In our study, the morphological and anatomical features of Euphorbia anacampseros Boiss. var. anacampseros taxon were examined.

The systematic of Euphorbia anacampseros Boiss. var. anacampseros taxon:

Regnum: Plantae

Phylum: Magnoliophyta

Classis: Magnoliopsida

Ordo: Malpighiales (Euphorbiales)

Family: Euphorbiaceae

Genus: Euphorbia

Species: anacampseros

Variety: anacampseros

Synonymous: Euphorbia anacampseros Boiss. var. minor

Euphorbia anacampseros Boiss. var. minor Boiss. in DC., Prodr., 15 (2): 174 (1862) was determined by Davis (1862).

As a result of limited research, Gökçen et al. (2018), in their morpho-anatomical study on Euphorbia anacampseros Boiss. var. anacampseros taxon observed anomocytic type stomata between leaf lower and upper surface epidermis cells.

\section{CONCLUSION}

In our study, some botanical features of E. anacampseros Boiss. var. anacampseros taxon such as morphological and anatomical structure. Besides this specimens were prepared for identification studies, especially in the herbarium symbol.

Due to the fact that E. anacampseros Boiss. var. anacampseros taxon, which has a natural distribution in the Kazdağ 1 ecosystem, which is important in the field of biodiversity on a world scale, is included in 122 Important Plant Areas (IPA) of our country, is especially endemic, is in the LC category and is of great economic importance, negative effects of possible climate changes are in particular. It's must to take the necessary precautions within the scope of protecting all biotic factors from harmful factors by in-situ or ex-situ methods of Kazdağ 1 National Park. 


\section{REFERENCES}

AVCI, M., 1993. Türkiye'nin Flora Bölgeleri ve 'Anadolu Diyagonali'ne Coğrafi Bir Yaklaşım. Türk Coğrafya Dergisi, 225-248.

AYLWARD, J.H., PARSONS, P.G., SUHRBIER, A., TURNER, K.A., 2016. Topical Use of Ingenol-3-Angelate or A Salt Thereof to Treat Skin Cancer. United States Patent. US 9,314.458 B2 Apr. 19, 2016.

BERCU, R., POPOVICIU, D.R., 2015. Comparative Anatomical Study on Leaves of Three Euphorbia L. Species. Wulfenia 22 (2015): 271-276.

DAVIS, P.H., 1982. Flora of Turkey and East Eagean Islands Vol 7 p: 611-612.

EKEN, G., BOZDOĞAN, M., İSFENDIYYAROĞLU, S., KILIÇ, D.T., LİSE, Y. 2006. Önemli Doğa Alanları Kitabı. Cilt: II s: 583.

AYAŞLIGİL, T., 2006. Kazdağları'nın Korunması ve Natura 2000 / Ekolojik Ağı. Kazdağları II. Ulusal Sempozyumu Bildirileri 22-25 Haziran 2006 s: 219-229.

ÖZHATAY, N., BYFIELD, A., ATAY, S., 2005. Türkiye'nin 122 Önemli Bitki Alanı Kitabı No: 18 s: 73-76.

GEMİĊ, Y., ÖZEL, N., 2001. Kazdağları'nda Flora ve Vegetasyon. Kazdağları I. Ulusal Sempozyumu Bildirileri. 20-22 Eylül 2001 s: 26-40.

GENÇ, Z., 1989. Bursa Çevresi ve Uludağ'ın Euphorbia Türleri. (Doktora Tezi). Uludağ Üniversitesi Fen Bilimleri Enstitüsü Biyoloji Anabilim Dalı. Erişim adresi: https://tez.yok.gov.tr/UlusalTezMerkezi

GÖKÇEN, Ü., KOYUNCU, O., SEZER, O., 2018. Euphorbia anacampseros Boiss. var. anacampseros Üzerine Morfo-Anatomik Araştırmalar. Research Journal of Biology Sciences 11(2): 11-13.

HECKER, E., 1986. Tumours Promoters of the Irritant Diterpene Ester Type as Risk Factors of Cancer in Man. International Symposium on Chemistry - 'Taxonomy and Economic Botany of Euphorbiales'.Botanical Journal of the Linnean Society London 1986.

LUZ, L.E.C., PALUDO, K.S., SANTOS, V.L.P., FRANCO, C.R.C., KLEIN, T., SILVA, R.Z., BELTRAME, F.L., BUDEL, J.M., 2015. Cytotoxicity of Latex and Pharmacobotanical Study of Leaves and Stem of Euphorbia umbellata (Janaúba). Revista Brasileira de Farmacognosia 25 (2015) 344-352.

MALI, P.Y., JADHAV, A.G., 2015. Assessment of Cytotoxicity of Aqueus Extract of Euphorbia hirta Against Human Lung Carsinoma and Vero Cell Line. Informatics Journals Volume 22 Issue 3 September - December 2015.

ERBAY, M.Ş., ANIL, S., MELIKKOĞLU, G., 2018. Plants Used as Painkillers in Folk Medicine in Turkey IV - TOOTHACHE. İstanbul J. Pharm 48 (2): 49-54.

ÖZGIŞİ, K., YAYLACI, Ö.K., SEZER, O., ÖZTÜRK, D., KOYUNCU, O., OCAK, A., 2017. Yunusemre Beldesi (Eskişehir) ve Çevresinin Florası. Süleyman Demirel Üniversitesi Fen Bilimleri Enstitüsü Dergisi Cilt 21, Sayı 1, 64-78, 2017.

ÇALIŞKAN V., 2010. Çanakkale İlindeki Bitkisel Kaynaklı Sağlık Risklerinin Değerlendirilmesi. Fırat Üniversitesi Sosyal Bilimler Dergisi. 20(1): 55-82. 
SCHIPPMANN, U., 2018. Plant Annotations in the CITES Appendices - An Illustrated Manuel. Convention on International Trade in Endangered Species of Wild Fauna and Flora. Twenty-fourth meeting of the Plants Committee Geneva (Switzerland), 20, 21 and 23-26 July 2018.

SEÇMEN, Ö., GEMİCI, Y., GÖRK, G., BERAT, L., LEBLEBİCİ, E., 2004. Tohumlu Bitkiler Sistematiği Ders Kitabı. Ege Üniversitesi Fen Fakültesi Kitaplar Serisi No: 110 s: 2540 .

YEŞILILURT, E.B., AKAYDIN, G., 2012. Endemic Plants and Their Treat Categories of Muğla Province (Turkey). Hacettepe J. Biol. \& Chem., 2012, 40 (2), 195-212. 